\title{
Suppressing communities: An analysis of LGBTQ+ censorship in libraries
}

\section{Taylor Stevens}

${ }^{1}$ School of Library and Information Studies, University of Alberta, Email: tlsteven@ualberta.ca To Cite:

Stevens, T. (2020). Suppressing communities: An analysis of LGBTQ+ censorship in libraries. Pathfinder: A Canadian Journal for Information Science Students and Early Career Professionals, 1(2), 51-62. https://doi.org/10.29173/pathfinder15

\begin{abstract}
Librarians serve as defenders of intellectual freedom and social responsibility, and this includes speaking out against censorship. Censorship of information, materials, and books occurs in the public, but it can also occur in libraries. Marginalized communities are affected the most by such censorship, such as the LGBTQ+ community. The purpose of this paper is to explore how internal, external, and institutional censorship affects the LGBTQ+ community, and what librarians can do to defend against censorship. Internal, or self-censorship, occurs at the librarian level where LGBTQ+ materials may be hidden by librarians or library staff, or simply not ordered due to pressure from the communities that libraries serve. External censorship occurs at the community level, where the community culture pushes for the censorship of LGBTQ+ materials. Lastly, institutional censorship occurs at the classification level, where classification models such as the Dewey Decimal System or subject headings may not provide accurate representations for LGBTQ+ materials. To put an end to these forms of censorship, trained and certified librarians must act as agents of change, committing to their due diligence to provide information to all members of their communities.
\end{abstract}

Keywords: Censorship, librarianship, LGBTQ+, internal censorship, external censorship, institutional censorship

ong gone are the days of librarians quietly shelving books or scanning the card catalogues, pushing their glasses up the bridge of their noses, and keeping their heads bowed. Long gone are the days of shushed libraries or libraries as hallowed and inflexible neutral grounds, as Berninghausen (1972) so boldly claimed in his essay. Many librarians are progressive within their field, actively engaging in social responsibility by allowing access to information and protecting their communities from censorship. As Lankes (2016) states: To be a librarian is "to be a radical positive change agent within [one's] community" (p. 3). 
LGBTQ+ collections and resources are often a source of controversy within American and Canadian libraries, where they face direct and indirect forms of censorship. The annual release of the American Library Association's (2013) Top 10 Banned Books displays LGBTQ+ censorship. For the past two years, books containing LGBTQ+ themes have made up half of the Top Ten lists of challenged books in libraries across the United States (American Library Association, 2013; Cavar, 2017; Glazer, 2017). As defenders of intellectual freedom and social responsibility, librarians have an obligation not only to serve and provide access to information to underprivileged communities but also to educate the general public about those communities. The purpose of this paper is to explore the impact of various forms of LGBTQ+ censorship within libraries. In it, I will discuss internal, external, and institutional forms of censorship, concluding with what librarians can do to serve the LGBTQ+ community better.

For inclusivity and the purpose of this paper, I will be using the acronym LGBTQ+ to represent the Lesbian, Gay, Bisexual, Transsexual, and Queer communities, along with those who do not identify as one of the former labels. According to McEachreon (2016), there are currently no best practices to determine the proper acronym, however, the plus sign (+) is a way to include the communities not represented in the former LGBTQ acronym. As the paper's author and a supporter of the LGBTQ+ community, I acknowledge the various identities represented only by the plus sign, and respect the communities within LGBTQ+ that have not been listed to the fullest extent.

\section{Internal Censorship}

Grandiose forms of censorship, such as book burning or statements of public outrage, are often associated with the censorship of LGBTQ+ materials (Downey et al., 2013). However, censorship is not always so vocal. It can be an inside job, so to speak, conducted by the library staff themselves. This is known as self-censorship and is defined as "the act of a librarian and his or her library promoting materials in accordance with a desire to avoid challenges from the public" (McEachreon, 2016, p. 192). Downey et al. (2013) claim self-censorship is often invisible and can easily be hidden by those committing the censorship through acts such as neglecting to replace a damaged book, claiming the materials were too expensive, or that the collection does not need new 
additions. These are cases where patrons would have no idea that, through the passive acts of librarians, materials were being censored (McEachreon, 2016). Downey et al. (2013) describe the "traps" librarians can fall into in regards to self-censorship, which include difficulties in finding LGBTQ+ books, claiming the books do not circulate, posing the question "what will it say about me?", professing there are no LGBTQ+ people in the community, and claiming there is no room in the budget for the purchase of such materials. Librarians are the gatekeeping intermediaries between patrons and books. They are the leaders in book selection and their own biases or prejudices should never impede this process, nor should popular opinion (Downey et al., 2013). Librarians must seek "a myriad of opinions represented by books that reflect the social and intellectual diversity of the world" (Jamison, 2018, para. 3). Self-censorship is an internal barrier to LGBTQ+ material access, and by participating, librarians are setting "a dangerous expectation that only certain groups should be allowed representation" (Pierson, 2017, p. 248).

Another common reason for self-censorship is the fear of backlash or controversy from the public. In the case of self-censorship in school libraries, librarians have been known to fear negative reactions from the parents of their student patrons (McEachreon, 2018). In fact, "according to a 2009 survey on self-censorship by School Library Journal, $70 \%$ of the library professionals claimed that concern about possible parent reactions factored into their decisions to acquire controversial titles" (Garry, 2015, p. 76). Parents, however, are not the only concern. Negative reactions can also come from the administration, the community, and the students themselves. Fear of this controversy, especially from those who have experienced it before, drives librarians to self-censor (Garry, 2015; Houde, 2018; Jamison, 2018; McEachreon, 2016). Garry (2015) claims librarians would go to great lengths to hide "controversial" LGBTQ+ materials. These librarians would claim there was no room in the budget, "hide" LGBTQ+ books in the adult shelves or remove searching identifiers within the catalog records to make the books more difficult to find (Garry, 2015). Self-censorship contradicts the ethical mindset a librarian is meant to represent - one meant to fight for intellectual freedom and social responsibility as a whole - which reflects poorly on the profession. As per the American Library Association's (2006) Library Bill of Rights, 
librarians should challenge censorship and ensure no one is denied access to resources based on their sexual orientation. Librarians have a moral and professional obligation to the LGBTQ+ community. Making these resources available to not only the LGBTQ+ community but also to allies and even the naysayers has the potential to teach those who may not understand the LGBTQ+ community and expand their horizons on the subject, thus creating a positive impact within the broader community.

If these issues are occurring internally within our libraries, how do we solve the problem of self-censorship? Pierson (2017) proposes furthering librarian education and training focused specifically on LGBTQ+ needs. In a study conducted in 2006 on more than one thousand school librarians from Arkansas, Delaware, and North Carolina, it was found that self-censorship was evident within librarians "holding no formal collegiate education degree (BSE or MS/MSE) with library media certification or licensure" (Rickman, 2010, p. 15). Formally trained librarians who have been educated in library studies, particularly on the subject of inclusion and social responsibility, are more likely to avoid censorship as they have the skills needed to develop well-rounded collections (Pierson, 2017). As Pierson (2017) states, "training is integral" (p. 254) to combating the lack of LGBTQ+ materials within library collections, reminding those in the profession of their professional and moral code and the patrons they serve, which, of course, includes the LGBTQ+ community. External assistance also exists in forms of LGBTQ+-focused groups within the library sciences field, such as IFLA's LGBT Users Special Interest Group (Glusac, 2018) and the American Library Association's (2009) Gay, Lesbian, Bisexual, and Transgender Round Table. The overall mission of these groups is to provide members with a "forum for discussion and an environment for education and learning regarding the needs of the gay, lesbian, bisexual, and transgender professional community and population at large" (American Library Association, 2009, para. 2).

\section{External Censorship}

According to an interpretation of the Library Bill of Rights, librarians are obligated to "select materials without regard to the sex, gender identity, or sexual orientation of their creators" (American Library Association, 2007, para. 4). Internal censorship is often committed by the library staff themselves, but another common form of censorship 
is one committed by external influences, such as the library's community itself. In the previous section, parents of students were briefly discussed as external forms of censorship, but this section will focus on the library's community at large. In Canada, homosexual acts were decriminalized in 1969; however, the United States' federal decriminalization of homosexual acts did not occur until 2003 (McEachreon, 2016). Canada preceded the United States in the legalization of same-sex marriage in 2005, while, as of 2014, only 35 states have legalized same-sex marriage (McEachreon, 2016). Despite the differences between these countries' societal shifts, the acceptance of LGBTQ+ materials has grown over time (Chemerinsky \& Gillman, 2017; Houde, 2018). Laws and legislation are changing, making gay rights relevant and current events (McEachreon, 2016). Despite the increasing acceptance of LGBTQ+ persons and materials available to the public, there are still several cases where these materials are censored. Although there are many examples, highlight the censorship of Drag Queen Story Hour and discuss a case study of the lowa LGBTQ+ book burning.

To showcase Drag Queen culture, libraries across Canada and the United States have partnered with Drag Queens in their communities to read stories to children. Drag Queen Story Hour (DQSH) (n.d.) "captures the imagination and play of the gender fluidity of childhood and gives kids glamorous, positive, and unabashedly queer role models" (para. 1). Yet, despite the program's positive message on gender fluidity, some libraries have encountered community backlash for hosting this program. At the Toronto Public Library, for instance, claims were made that the program was indoctrinating and "grooming" children (Shakeri, 2018). DGSH was deemed a "cancer" by a blogger discussing the program in Illinois libraries (Higgins, 2017). Much like the previously discussed instances of self-censorship, librarians are feeling pressure from their communities to pull these types of LGBTQ+ programs due to public outcry. The mayorpresident of Lafayette, Louisiana was concerned about DGSH at a local public library and said he planned to cancel the event (Mastricolo, 2018). However, in this case, the citizens of Lafayette supported the program, and the National Coalition Against Censorship stood against the mayor-president's decision (Mastricolo, 2018). Even those who disagreed with the program argued it was not right to cancel it (Mastricolo, 2018). 
Another case of external censorship was the lowa book burning. Paul Dorr, a resident of Orange City, lowa, and director of a pro-life, anti-homosexuality group, checked out LGBTQ+ books from the local public library and burned them on video broadcasted across the internet (Dockter, 2018). Dorr's protest is an extreme example of censorship from the public, but his actions showcase a real, shared mentality that still exists within the public today. Additionally, while this was an isolated event, it showcases the lengths to which the public may go to censor ideas they do not believe in. Librarians find themselves in a unique position of serving both sides of the community: those who oppose LGBTQ+ materials and the LGBTQ+ community itself. How do librarians protect the LGBTQ+ community from external censorship?

Libraries' openness and transparency are key in developing a positive relationship between them and their community. Libraries can be powerful allies in providing LGBTQ+ materials for the LGBTQ+ community, while simultaneously educating the rest of the public. The first step, and a simple one that starts at the source, is for librarians to understand the LGBTQ+ community (Houde, 2018). Dispelling misconceptions and myths, and keeping oneself informed about the LGBTQ+ community aids in educating the greater public (Houde, 2018). Librarians can also map out their communities to know more about their LGBTQ+ population and the services needed (McEachreon, 2016).

Another method by which librarians can limit LGBTQ+ censorship from external sources is through library-community partnerships. Partnerships with community organizations and volunteers to support LGBTQ+ communities and interests has the potential to engage not only members of the LGBTQ+ community, but members of the greater public as well, providing an educational opportunity (McEachreon, 2016). The normalization of the LGBTQ+ community through community partnerships streamlines its public acceptance. Finally, librarians can display collections, materials, and art to convey their support for the LGBTQ+ community. An example is the Reverse Vandalism project undertaken by the San Francisco Public Library in 2004 (McEachreon, 2016), which was conducted as follows (San Francisco Public Library, n.d.):

"In early 2001, San Francisco Public Library staff began finding vandalized books shoved under shelves, hidden throughout the Main Library. Ultimately over 600 
torn and sliced books, on gay, lesbian, bisexual, and transgender topics, women's issues and HIVIAIDS were deemed beyond repair and withdrawn from the Library's collection. Rather than discard the damaged books, the Library distributed them to interested community members in the hope of creating art. The wide variety of artistic responses to this hate crime resulted in "Reversing Vandalism," an exhibition of over 200 original works of art, displayed in the Main Library from January 31 through May 2, 2004" (para. 1).

Projects such as Reverse Vandalism are a way to educate the public by introducing alternate lenses that address discrimination in LGBTQ+ communities and remind the public that censorship is still alive and well in the present day.

As indicated by McEachreon (2016), there has been great progress towards the improvement of LGBTQ+ human rights, but "there is still work to be done" (p. 190). Libraries who continue to create partnerships within their communities can be a part of the solution, much like the San Francisco Public Library's 'Reverse Vandalism' project, to create a community that is no longer 'us vs. them', but rather a cohesive community of understanding.

\section{Institutional Censorship}

Lastly, censorship of LGBTQ+ materials can originate at the institutional level. This institutional censorship can be seen in library subject headings; controlled vocabulary and cataloguing methods, such as the Dewey Decimal Classification (DDC); and curriculum restrictions and internet filtering within school and public libraries. Subject headings in library catalogues are used to guide a patron to a material's categorization and aid them in finding the material right for them (Library of Congress, n.d.). Commonly used subject headings are the Library of Congress Subject Headings (LCSH) and Sears subject headings. The LCSH have been used to catalogue Library of Congress (LOC) materials since 1898 and are used as subject headings in various libraries throughout the United States and Canada (Library of Congress, n.d.; McClary \& Howard, 2007). These subject headings reflect the current culture of the times in which they are developed, and, "designed to provide access to materials to non-specialists" (Johnson, 2010), they determine how materials are categorized for the general public. Over time, outdated subject headings reflected in the LCSH have been improved or 
corrected (Johnson, 2010; McClary \& Howard, 2007). McClary and Howard (2007) note that terms referring to homosexuality "are not static, but are continuously changing and evolving, making the selection of appropriate and useful catalogue terms particularly challenging" (p. 152). McClary's and Howard's (2007) study looked at the use of subject headings for LGBTQ+ young adult (YA) and adult fiction in urban Canadian libraries. They found "YA titles in general have a higher rate of being assigned [Gay, Lesbian. Bi. Trans]-specific subject headings than do adult titles" (McClary \& Howard, 2007, p. 157); however, less than half of the books they analyzed had the appropriate subject headings for their content. While this lack of proper cataloguing may not be intentional censorship, it arises within a system grounded in institutionalized censorship (Pierson, 2017), which limits discovery and access to LGBTQ+ materials for patrons, hiding the materials within the catalogue.

Sears subject headings were developed in 1923 and, like LCSH, the "changes in subject headings have reflected the changes in society" (Marcus, 2012, p. 5), particularly for LGBTQ+ terminology. In 2007, after more states began embracing marriage equality, the Sears headings were changed to reflect LGBTQ+ terminology, including headings such as "Gay rights, Gay parents, and Ordination of gays and lesbians" (Marcus, 2012, p. 5). As with the LCSH, Sears headings were slow to change, but Marcus (2012) addresses the crucial point that "keeping track of changes in terminology is especially important for young people and others who search for books that mirror their personal experience" (p. 5). Developing more current and familiar subject headings decreases the potential for institutionalized censorship, reminding librarians to adhere to their obligation to provide access to anyone, regardless of their sexuality or identity.

Censorship through curricula has a trickle-down effect that enhances the previously mentioned forms of censorship within the public and among librarians. The culture in which the school or school district resides will affect the curricula (Pierson, 2017); If the education system creates barriers to LGBTQ+ information and materials, this will be reflected in the public's perspective on LGBTQ+ communities (Pierson, 2017). As discussed by Pierson (2017), these barriers are often seen in the American 
educational system as "eight states in the United States [...] legally prohibit LGBTQ+inclusive curriculum development" (p. 248).

Additionally, internet filtering is common within school and public libraries and, depending on the institution and the culture surrounding it, words and subjects relating to the LGBTQ+ community may be filtered (Pierson, 2017). Pierson (2017) acknowledges that this may be an extreme case of censorship; however, restricting online access to LGBTQ+ information within public spaces can negatively impact members of the LGBTQ+ community, especially young people who seek information in what are meant to be safe spaces (Pierson, 2017). The Kaiser Family Foundation conducted a study in 2002, which focused on testing "access to health information sites for teens by surveying seven commonly used filters" (Schrader, 2009, p. 108). The results of the study found that " $60 \%$ of lesbian and gay health sites" were blocked for teens (Schrader, 2009, p. 108), indicating a significant form of censorship restricting LGBTQ+ teen access.

\section{Conclusion}

The legalization of same-sex marriage in Canada and the United States, and the subsequent immersion of LGBTQ+ perspective into media, have caused a cultural shift. With any cultural shift controversy emerges. Censorship is meant to hide or suppress controversial topics, in that it is "an action that seeks to remove parts or all of a work, and [is] usually due to what in the material the censor deems as obscene" (Houde, 2018, p. 63). I have discussed the causes of internal, external, and institutional censorship, and suggested resolutions. The suggestions I have presented may impact communities on a small scale, as more significant reductions in the censorship of LGBTQ+ materials will require a larger shift in cultural perspective. As Pierson (2017) suggests, the most feasible solution to the problem at hand is time. The removal and censorship of LGBTQ+ materials within libraries has gradually decreased and will continue to do so; however, it is up to librarians to make an impact by observing due diligence and upholding their commitment to intellectual freedom and social responsibility. Librarians must provide access to information for all members of the community (American Library Association, 2017). It is through this access they can be 
agents of change (Lankes, 2013), establishing an inclusive community in which valuable information about and for its LGBTQ+ members is no longer restricted.

\section{Conflict of Interest Statement}

None declared.

\section{References}

American Library Association. (2006). Library bill of rights.

\section{http://www.ala.org/advocacy/intfreedom/librarybill}

American Library Association. (2007). Access to library resources and services regardless of sex, gender identity, gender expression, or sexual orientation. http://www.ala.org/advocacy/intfreedom/librarybill/interpretations/accesslgbt

American Library Association. (2009). GLBTRT bylaws \& mission statement. from http://www.ala.org/rt/glbtrt/about/bylaws

American Library Association. (2013). Top ten most challenged books lists. http://www.ala.org/advocacy/bbooks/frequentlychallengedbooks/top10

American Library Association. (2017). Professional ethics.

\section{http://www.ala.org/tools/ethics}

Berninghausen, D. K. (1972). Antithesis in librarianship: Social responsibility and the library bill of rights. Library Journal, 97(20), 3675-3681.

Cavar, S. (2017, October 5). 2017 sees increase in LGBT books challenged by parents. http://www. mountholyokenews.com/books/2017/10/5/2017-sees-increase-in-lgbtbooks-challenged-by-parents

Chemerinsky, E., \& Gillman, H. (2017). Free speech on campus. New Haven, Yale University Press.

Dockter, M. (2018, October 21). NW lowa religious activist burns LGBTQ library books in protest of OC Pride. Sioux City Journal. https://siouxcityjournal.com/news/local/nw-iowa-religious-activist-burns-lgbtqlibrary-books-in-protest/article 0ae4c328-5814-5674-bb8d-6120a9a7d020.html

Downey, J., Antell, K., \& Strothmann, M. (2013). Self-censorship in selection of LGBT themed materials. Reference and User Services Quarterly (2), 104-107. https://www-jstor-org.login.ezproxy.library.ualberta.ca/stable/refuseserq.53.2.104

Drag Queen Story Hour. (n.d.). About. 
SUPPRESSING COMMUNITIES

\section{https://www.dragqueenstoryhour.org/\#about}

Garry, C. P. (2015). Selection or censorship? School librarians and LGBTQ resources. School Libraries Worldwide, (1), 73-143. DOI:10.14265.21.1.005

Glazer, G. (2017, September 25). Top 5 most-challenged books of 2016 include LGBTQ themes [Blog post]. https://www.nypl.org/blog/2017/09/25/most-challengedbooks-2016-lgbta

Glusac, L. (2018). Local public libraries as human rights intermediaries. Netherlands Quarterly of Human Rights (2), 133-151. https://doi.org/10.1177/0924051918772968

Higgins, L. (2017, May 25). Drag queens, "queers," and toddler, oh my! [Blog post]. https://illinoisfamily.org/homosexuality/drag-queens-homos-toddlers-oh/

Houde, L. (2018). Serving LGBTQ teens: A practical guide for librarians [eBook]. Lanham: Rowman \& Littlefield.

Jamison, A. (2018, May 8). Librarians beware: Self-censorship [Blog post]. https://www.oif.ala.org/oif/?p=13550

Johnson, M. (2010). Transgender subject access: History and current practice. Cataloging and Classification Quarterly, 48(8), 661-683. https://doi.org/10.1080/01639370903534398

Lankes, R. D. (2016). The new librarianship field guide. Cambridge, MA: MIT Press. Library of Congress (n.d.). Library of Congress subject headings.

http://id.loc.gov/authorities/subjects.html

Marcus, S. R. (2012). The changing terms in Sears headings. Judaica Librarianship, 16, 113-124. https://doi.org/10.14263/2330-2976.1007

Mastricolo, P. (2018, August 24). Louisiana mayor critical of Drag Queen Story Hour [Blog post]. http://cbldf.org/2018/08/louisiana-mayor-critical-of-drag-queen-story$\underline{\text { hourl }}$

McClary, C., \& Howard, V. (2007). From homosexuality to transvestites : An analysis of subject headings assigned to works of GLBT fiction in Canadian public libraries : LGBTQ. Canadian Journal of Information and Library Science (2), 149-162. http://pascal-francis.inist.fr/vibad/index.php?action=search\&terms=21022678 McEachreon, P. (2016). Libraries "coming out" in support of LGBTQIA+ human rights 
and social justice. In U. Gorham, N. G. Taylor, \& P. T. Jaeger (Eds.), Perspectives on libraries as institutions of human rights and social justice (pp. 183-208). Bingley, UK: Emerald Group Publishing Limited.

Pierson, C. M. (2017). Barriers to access and information for the LGBTQ community. The Canadian Journal of Information and Library Science, 41(4), 245-262. https://doi.org/10.3138/cjils.41.4.e17023

Rickman, W. (2010). A study of self-censorship by school librarians. Research Journal of the American Association of School Librarians, 13, 1-21. http://www.ala.org/aasl/sites/ala.org.aasl/files/content/aas/pubsandjournals/slr/vo 13/SL StudyofSelf-Censorship V13.pdf

San Francisco Public Library. (n.d.). Reversing vandalism. https://sfpl.org/?pg=2000111401

Schrader, A. M. (2009). Challenging silence, challenging censorship, building resilience: LGBTQ services and collections in public, school and post-secondary libraries. Feliciter, (3), 107-108. https://doi.org/10.7939/R3R785R8X

Shakeri, S. (2018, September 21). Drag Queen Storytime at Toronto Public Library tries to 'indoctrinate kids': LifeSiteNews. Huffington Post. https://www.huffingtonpost.ca/2018/07/21/drag-queen-storytime-at-torontopublic-library-tries-to-indoctrinate-kids-lifesitenews a 23486901/ 